\title{
The Role of Langmuir-Blodgett (Lb) Protein Thin Film in Protein Crystal Growth by Lb Nanotemplate and Robot
}

\author{
Eugenia Pechkova ${ }^{1 *}$, Stefano Fiordoro', Francesca Barbieri' and Claudio Nicolini ${ }^{1,2}$ \\ ${ }^{1}$ Research laboratory and Academic unit of Clinical Rheumatology, DiMI, University of Genoa, Italy \\ ${ }^{2}$ Nanoworld Institute Fondazione ELBA Nicolini, Pradalunga, Largo Redaelli 7, Bergamo, Italy
}

\begin{abstract}
The crystal growth of biological macromolecules is a very complicated process involving numerous parameters, such as pressure, $\mathrm{pH}$, micro-gravity, photochemical and mechanical induction of nucleation. The utilization of Langmuir-Blodgett (LB) thin film as a template plays an important role in order to produce well-diffracting, stable and radiation-resistant protein crystals. LB nanotemplate crystallization method is a modification of the classical hanging drop vapor diffusion method. We tested four standard proteins, changing different parameters such as protein and salt concentration, number of LB layers etc., in order to verify the real role of LB template. Our results suggest that LB template essentially acts in two way on crystallization: in nucleation and in crystal growth. The possible explanation of these effects is also discussed.
\end{abstract}

Keywords: Classical hanging drop vapor diffusion method; Langmuir-Blodgett (LB) protein thin film; Lysozyme; Ribonuclase A; Proteinase K; Thaumatin

\section{Introduction}

Protein crystallography will remain the most powerfull tool for protein $3 \mathrm{D}$ structure investigation in the foreseeable future [1,2]. It is essential instrument enable to helping to provide new insights for drug development and for the understanding of molecular mechanisms [3].

The growth of macromolecular crystals and the influence of chemical and biochemical parameters on their solubility are quite understood, but in order to gain a better and more precise understanding of the effect of physical parameters, such as temperature, magnetic, electric and gravitational fields [4], further investigations are needed.

The nucleation and the growth of crystals from aqueous solutions are influenced by physical chemical variables and are altered by convective currents due to gradients caused by temperature [5] and concentration difference [6], whilst this gradient is minimal in microgravity [7]. Using LB technology is possible to improve both crystal radiation stability [8] and quality of diffraction [9].

In the process of protein crystallization, nucleation is an important first step for crystal growth [10]. Several research studies have demonstrated that inorganic crystals can be used as nucleant [11]. Recent investigations have proven that inorganic materials (such as micromica and chlorite [12], complex interfaces and patterns formed by self-assembly monolayers, called SAMs, on gold [13]) can regulate nucleation because these materials can accelerate the induction of nucleation and generate larger crystals [14]. Several studies were conducted in order to investigate the effect of $\mathrm{pH}$ on crystal growth [15] or the mechanisms of photochemically-induced crystallization [16].

Results of previous studies demonstrated that a nanostructured protein template could stimulate nucleation and crystal growth. Using this new technique, human CK2 was successfully crystallized [3] and the role of water was madee evident [17].

In the present work we studied the role of LB thin film as template in order to evaluate the changes in crystal growth and the LB contribution to crystal growth at very low concentration of protein.

We developed a modification of classical hanging drop vapor diffusion method (Figure 1A) with the aim of obtaining an acceleration in crystal growth and a minimization in the protein concentration required for crystal growth, called "critical concentration".

We used four different model proteins: lysozyme, thaumatin, ribonuclease $\mathrm{A}$ and proteinase $\mathrm{K}$ (Table 1). We chose these proteins since they are very extensively studied via different crystallographic methods and therefore may constitute a good starting point to shed new lights on experimental parameters of LB crystallization technique.

Lysozyme, EC 3.2.1.17, is an enzymes which damages bacterial cell walls by hydrolysis of linkages in peptidoglycan and in chitodextrins. Thaumatin, P02883, is a low-calorie (virtually calorie-free) protein sweetener and flavor modifier. Ribonuclease, usually abbreviated in RNase, EC 3.1.27, is a nuclease that catalyzes the hydrolysis of RNA into smaller components. Proteinase K (also protease K or endopeptidase $\mathrm{K})$, EC 3.4.21.64, is a broad-spectrum serine protease.

\section{Materials and Methods}

\section{Proteins}

Lysozyme (cat. L6876), proteinase K (cat. P6556), thaumatin (cat. T7638) and ribonuclease A (cat.R5125) were purchased by Sigma Aldrich (Milano, Italy). The proteins were filtered through a 0.45 $\mu \mathrm{m}$ mesh size filter (Millipore, Carrigtwoill, Co. Cork, Irleand) and reservoirs were filtered through a $0.20 \mu \mathrm{m}$ mesh size filter (Albet-Jacs) before the experiments were set up. The Atomici force microscopy of the Langmuir-Blodgett monolayer of one the above typical model proteins being here utilized, namely Lysozyme, is shown in Figure 1B along with correspondeng isotherm (on the left).

*Corresponding author: Eugenia Pechkova, Research laboratory and Academic unit of Clinical Rheumatology, DiMl, University of Genoa, Italy, Tel: 39-0103533822; E-mail: eugenia.pechkova@gmail.com

Received September 22, 2014; Accepted November 24, 2014; Published December 02, 2014

Citation: Pechkova E, Fiordoro S, Barbieri F, Nicolini C (2014) The Role of Langmuir-Blodgett (Lb) Protein Thin Film in Protein Crystal Growth by Lb Nanotemplate and Robot. J Nanomed Nanotechnol 5: 247. doi: 10.4172/21577439.1000247

Copyright: (C) 2014 Pechkova E, et al. This is an open-access article distributed under the terms of the Creative Commons Attribution License, which permits unrestricted use, distribution, and reproduction in any medium, provided the original author and source are credited. 


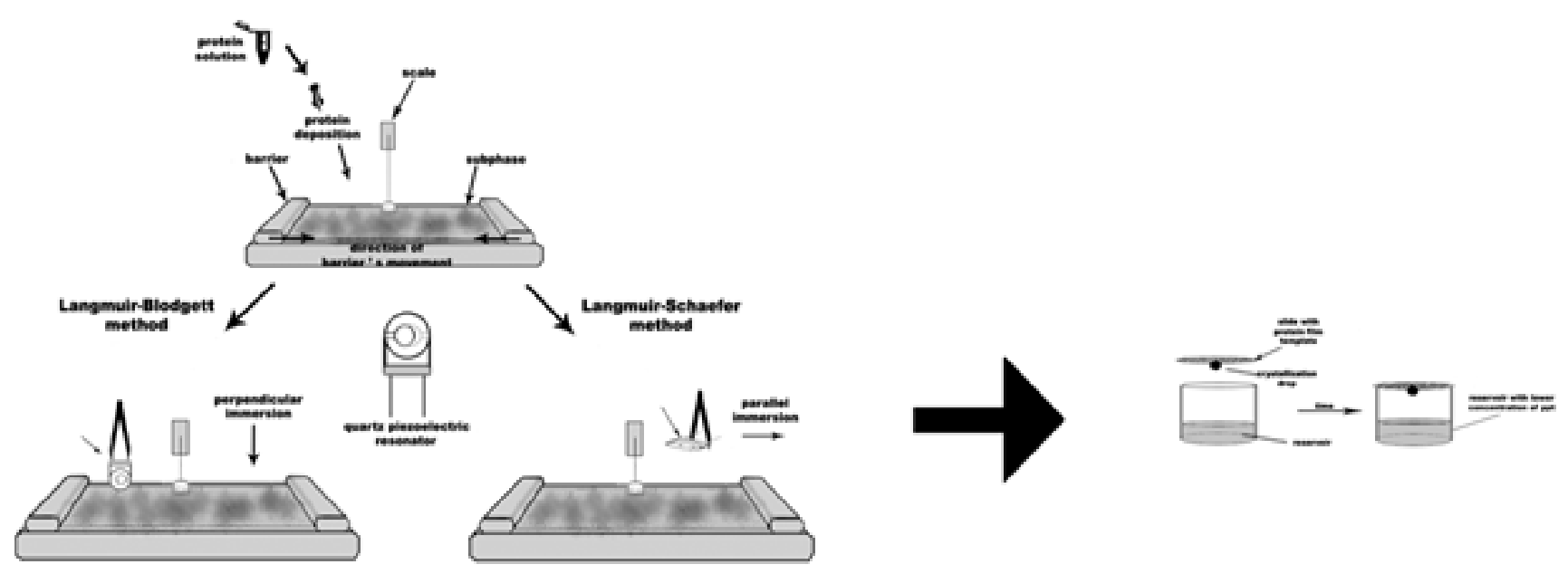

Figure 1a: Robot experimental layout of LB crystallization.

\begin{tabular}{|c|c|c|c|}
\hline Parameter & LB & Classical & Classical 2 \\
\hline Resolution $(\AA)$ & $1.6-45.23$ & $1.6-45.79$ & $1.6-45.83$ \\
\hline $\mathrm{a}, \mathrm{c}($ where $\mathrm{a}=\mathrm{b})$ & $58.099,150.409$ & $57.782,150.219$ & $57.797,150.271$ \\
\hline Completeness (\%) & 99.52 & 91.25 & 98.93 \\
\hline R-factor & 0.20571 & 0.18695 & 0.18349 \\
\hline $\mathrm{R}_{\text {mrg }}$ & 0.128 & 0.060 & 0.061 \\
\hline I/Sigma & 4.2 & 8.4 & 7.7 \\
\hline Water & 235 & 264 & 265 \\
\hline Number of unique reflections & 33059 & 29913 & 32470 \\
\hline Redundancy & 0.138 & 0.068 & 0.070 \\
\hline Cell Volume & 507704.64 & 501545.11 & 501979.255 \\
\hline
\end{tabular}

Table 1: LB thin film and crystal growing conditions.

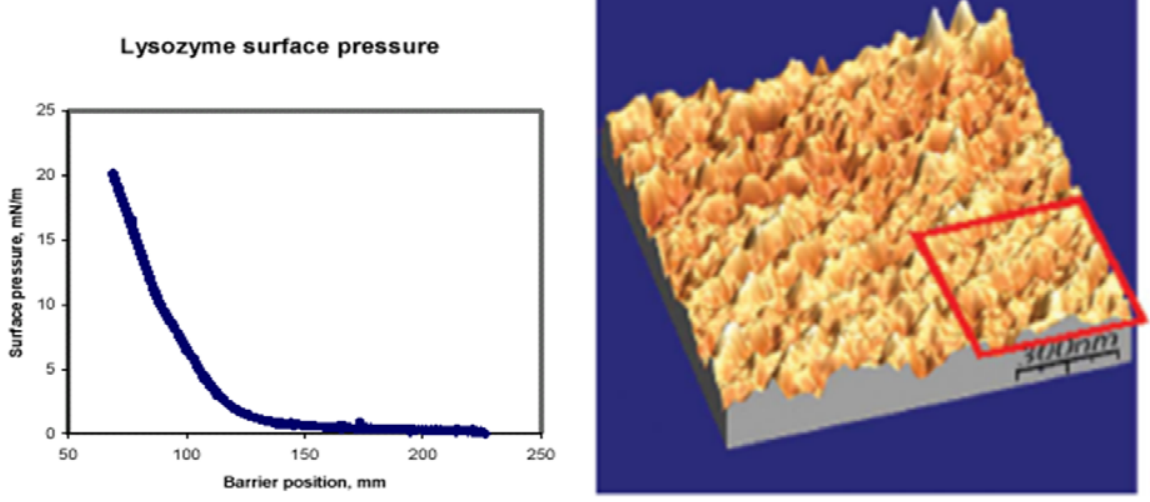

Figure 1b: Isotherm and Atomic Force Microscopy of Lysozyme Langmuir-Blodgett film.

\section{Vapor diffusion/hanging drop method}

Vapor diffusion methods based on LB nanotempalte method (Figure 1) involve an aqueous drop containing the macromolecule and the crystallization agents in a lower amount than that required for the formation of crystals. This drop $(2-4 \mu \mathrm{l})$ is equilibrated against a reservoir $(1 \mathrm{ml})$ containing a solution of crystallizing agents at a higher concentration. Equilibration proceeds by diffusion of the volatile species (water or organic solvent) until vapor pressure in the drop equals that of the reservoir. Consequently, the concentration of all constituents in the drop will change. The reservoir acts in a such way to gradually concentrate the drop, and this gradual change in concentration may lead to crystallization.

The crystallization process can be illustrated by a phase diagram for all four model proteins being studied (Figure 1), that shows which state 

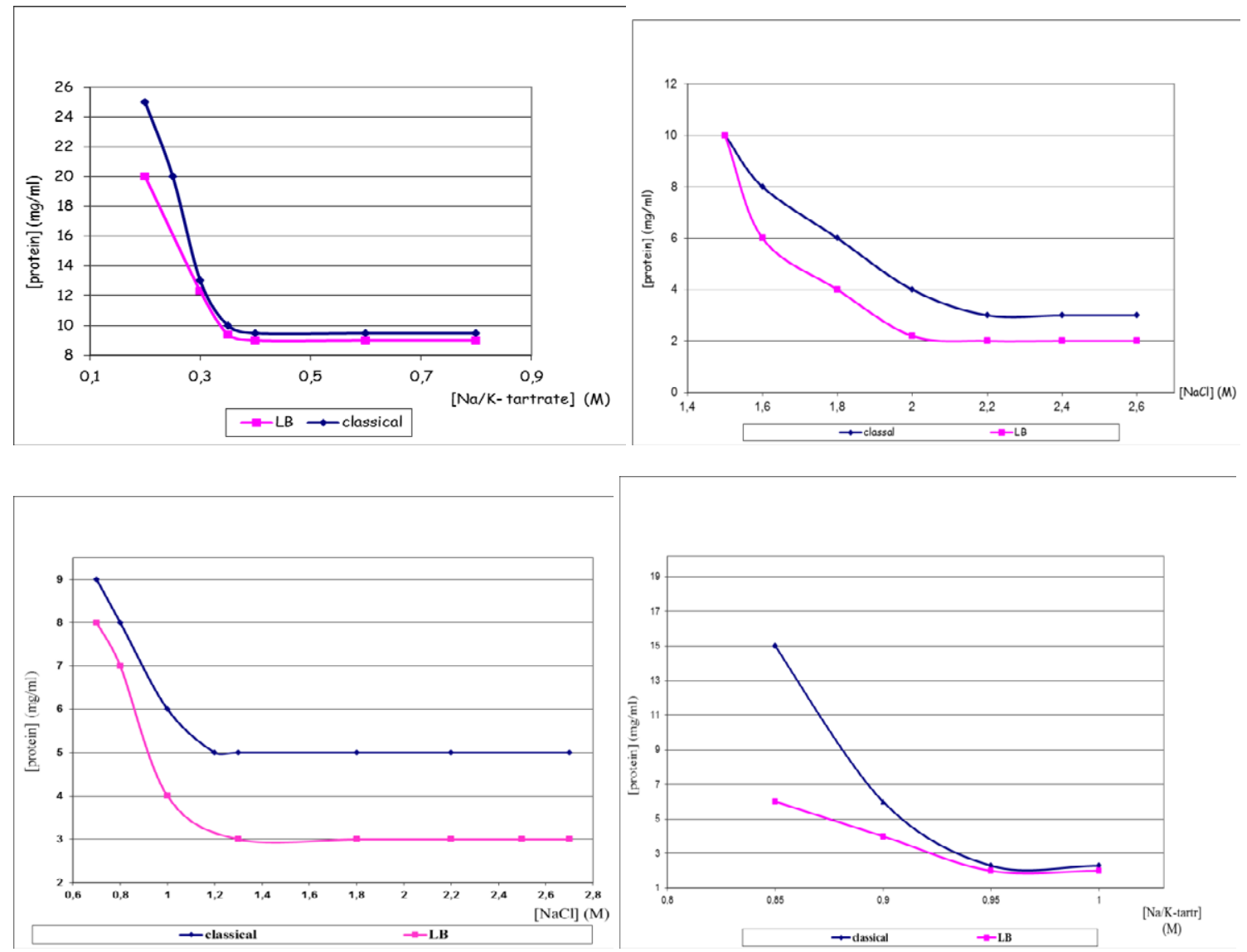

Figure 1c: Phase Diagrammes of Proteinase k, Ribonuclease, Lysozyme and Thaumatin

(liquid, crystalline or amorphous solid [precipitate]) is stable under a variety of crystallization parameters. It provides a means of quantifying the influence of different parameters (concentrations of protein, precipitant(s), additive(s), $\mathrm{pH}$ and temperature) on the production of crystals. Hence, phase diagrams form the basis for the rationale design of crystal growth [18].

The crystallization conditions used for hanging-drop method were a $4 \mu \mathrm{l}$ drop containing $40 \mathrm{mg} / \mathrm{ml}$ of lysozyme in $50 \mathrm{mM}$ sodium acetate buffer $\mathrm{pH} 4.5$ placed on the siliconized glass slide and stabilized over the reservoir containing $0.9 \mathrm{M}$ sodium chloride in $50 \mathrm{mM}$ sodium acetate buffer $\mathrm{pH} 4.5$. For thaumatin, we used a $4 \mu \mathrm{l}$ drop containing $15 \mathrm{mg} /$ $\mathrm{ml}$ of protein in $100 \mathrm{mM}$ ADA buffer $\mathrm{pH} 6.5$ placed on the siliconized glass slide and stabilized over the reservoir containing $1 \mathrm{M}$ sodium/ potassium tartrate in $100 \mathrm{mM}$ sodium/potassium tartrate buffer $\mathrm{pH}$ 6.5. For ribonuclease A, we used a $4 \mu \mathrm{l}$ drop containing $10 \mathrm{mg} / \mathrm{ml}$ of protein in $50 \mathrm{mM}$ sodium acetate buffer $\mathrm{pH} 5.5$ placed on the siliconized glass slide and stabilized over the reservoir containing $1.75 \mathrm{M}$ bis-ammonium sulfate and $2.0 \mathrm{M}$ sodium chloride in $100 \mathrm{mM}$ sodium acetate buffer $\mathrm{pH}$ 5.5. The crystallization conditions used for hanging-drop method for proteinase $\mathrm{K}$ were a $4 \mu \mathrm{l}$ drop containing $20 \mathrm{mg} / \mathrm{ml}$ of protein in $25 \mathrm{mM}$ HEPES buffer $\mathrm{pH} 7.0$ placed on the siliconized glass slide and stabilized over the reservoir containing $400 \mathrm{mM}$ sodium/potassium tartrate in 25 mM HEPES buffer $\mathrm{pH}$ 7.0.

For all standard proteins, we observed crystal growth for one week.

\section{LB thin films}

LB films were prepared using a LB trough (MDT, Moscow) $[19,20]$. The formation of a monolayer was performed by compressing the barriers to reach the surface pressure of deposition [21]. The films were then transferred onto a siliconized cover glass slide.

The proteins were spreaded onto air-water interface and then were compressed to the desired surface pressure by means of LB trough with distilled water purified with MilliQ system $(18.2 \mathrm{M} \Omega \mathrm{cm})$ used as subphase. Protein solution, after filtration with Millex HV $(0.45 \mu \mathrm{m}$ Filter Unit, Millipore, Co. Cork, Ireland) were spreaded over the water surface with Hamilton syringe. The protein monolayer was compressed immediately after spreading. The transfer of protein monolayer from the subphase surface onto solid support was performed by touching the support in parallel to the subphase surface according to LangmuirSchaefer (LS) technique (horizontal lift) [22] at the desired protein surface pressure. Siliconized circle glass cover slides (Hampton Research, Laguna Niguel, CA) washed in distilled water and dried in nitrogen flux were used as substrate for the protein thin film deposition.

The protein monolayer transferred from the air-water interface onto the siliconized glass cover slide was used as a template for modification of classical vapor diffusion hanging drop method [23,24] (Figure 1).

For all proteins we used the same experimental conditions (as described in Table 1). 
Citation: Pechkova E, Fiordoro S, Barbieri F, Nicolini C (2014) The Role of Langmuir-Blodgett (Lb) Protein Thin Film in Protein Crystal Growth by Lb Nanotemplate and Robot. J Nanomed Nanotechnol 5: 247. doi: 10.4172/2157-7439.1000247

\section{Nanogravimetric measurement}

The surface density of protein on the LB films was measured by successive layer deposition on the quartz piezoelectric resonator AT cut (resonance frequency $10 \mathrm{MHz}$ ) of a home-built nanogravimetric gauge [25]. A circuit allows the quartz resonator to oscillate at its resonance frequency. The shift in resonance frequency, induced on the quartz resonator by subsequent LB deposition, was monitored by a frequency meter.

The shift in the resonance frequency $\Delta f$ after deposition correlates with the surface density $\Delta s$ of the mass deposited as described by the well-known Sauerbrey equation, $\Delta \mathrm{s}=-\mathrm{K} \cdot \Delta \mathrm{f}$, where $K$ is a constant whose value was estimated to be about $0.0295 \mathrm{ng} \mathrm{Hz}^{-1} \mathrm{~mm}^{2}$ according to the procedure reported in literature [26].

\section{Crystal growth: LB hanging drop method}

A nanotemplate-based crystallization method was utilized as described in Pechkova and Nicolini [27]. This LB protein thin film assumes the role of template for protein nucleation and crystal growth. A highly ordered protein nanotemplate was utilized in a modified hanging-drop protein crystallization method: the drop of protein solution and precipitant was placed on the glass slide covered by LB thin film. Like in the classical hanging-drop method, the glass slide with the protein template and the drop was sealed on the crystallization plate (Limbro plate, Hampton Research) using vacuum grease.

For each protein growing conditions were different (Table 2). For comparison, the same conditions were used to obtain crystals by the classical handing-drop crystallization method.
Crystals were grown at $20^{\circ} \mathrm{C}$ in hanging drops, using Limbro plates containing $1 \mathrm{ml}$ of reservoir solutions. $3 \mu \mathrm{l}$ of protein solution were mixed with $3 \mu$ l of reservoir solution in order to form the protein drops. This method seems to produce radiation stable crystals [28].

In order to control nucleation, it is necessary to work in very clean conditions: protein solution was filtered with Millex HV $(0.45 \mu \mathrm{m}$ Filter Unit, Millipore) and reservoir solution was filtered with Cellulose acetate syringe filter $(0.20 \mu \mathrm{m}$ pore, Albet-Jacs).

\section{Data reduction}

$\mathrm{X}$-Ray diffraction data for these crystals were collected at ESRF ID14-1 beamline. Exposure time for each image was 0.5 seconds and wavelength of X-Rays used was 0.934 Angstrom. Total 50 well diffracting images were obtained for both LB and classical crystals using ADSC CCD detector. Crystal to detector distance 136.94 in all cases. Following steps were used for data reduction.

Images were integrated using Mosflm. Scala and Refmac5 [29] were used from CCP4 suit for scaling and refining the coordinates. Electron density map of the proteins was computed using Coot. Water addition was done at 1sigma.

\section{LB-based robot automatization}

We coupled LB crystallization with a fully automated system for crystallization and X-ray data collection. Instead of separated steps in which crystals are being transferred from crystallization supports to X-ray data-collection supports, we used a new approach which enables full automation of the crystal-harvesting process. Challenging and demanding steps, such as the delicate and crucial moments of

\begin{tabular}{|c|c|c|c|c|c|c|c|c|}
\hline Protein & $\begin{array}{l}\text { Film pressure } \\
(\mathrm{mN} / \mathrm{m})\end{array}$ & $\begin{array}{l}\text { Protein concentration } \\
\text { in film }(\mathrm{mg} / \mathrm{ml})\end{array}$ & $\begin{array}{l}\text { Spreaded } \\
\text { volume }(\mu \mathrm{I})\end{array}$ & $\begin{array}{l}\text { Protein solution } \\
\text { in drop }(\mu \mathrm{l})\end{array}$ & $\begin{array}{l}\text { Reservoir solution } \\
\text { in drop }(\mu \mathrm{l})\end{array}$ & \begin{tabular}{|} 
Reservoir solution \\
in well (ml)
\end{tabular} & $\begin{array}{l}\mathrm{T} \\
\left({ }^{\circ} \mathrm{C}\right)\end{array}$ & $\begin{array}{l}\text { Number of } \\
\text { layers }\end{array}$ \\
\hline Ribonuclease A & 20 & 5 & 100 & 3 & 3 & 1 & 2 & 2 \\
\hline Proteinase $\mathrm{K}$ & 20 & 10 & 100 & 3 & 3 & 1 & 2 & 2 \\
\hline Thaumatin & 20 & 1 & 50 & 3 & 3 & 1 & 2 & 2 \\
\hline
\end{tabular}

Table 2: Crystallographical comparison between LB and classical crystals.

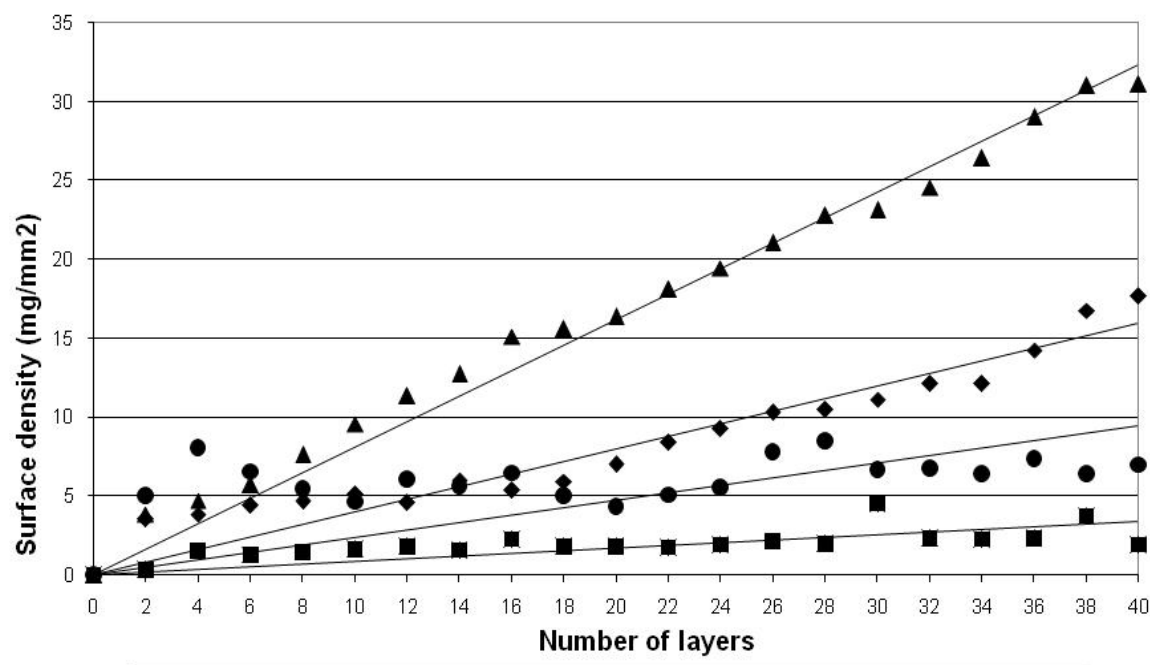

- Ribonuclease A •Proteinase K $\Delta$ Lysozyme • Thaumatin

Figure 2: Dependence of the surface density of deposited ribonuclease A, thaumatin, proteinase $\mathrm{K}$ and lysozyme nanostructured films upon the number of transferred protein mono-layers, at $20 \mathrm{mN} / \mathrm{m}$ of pressure. 
Citation: Pechkova E, Fiordoro S, Barbieri F, Nicolini C (2014) The Role of Langmuir-Blodgett (Lb) Protein Thin Film in Protein Crystal Growth by Lb Nanotemplate and Robot. J Nanomed Nanotechnol 5: 247. doi: 10.4172/2157-7439.1000247

Page 5 of 9

"crystal fishing", crystal handling and crystal mounting, are now fully operationally integrated $[30,31]$.

\section{Results}

\section{Nanogravimetric measurement}

For each protein we tested the constant increase of protein deposition onto the quartz. We found that, for all standard proteins, the rate of deposition was constant in dependence on number of immersion. However, for each protein the quantity of deposited protein was different. For ribonuclease A the surface density was very low: after 20 depositions was around $3 \mathrm{mg} / \mathrm{mm}^{2}$. For proteinase $\mathrm{K}$, the surface density was low but was greater than ribonuclease A: after 20 depositions was around $7.5 \mathrm{mg} / \mathrm{mm}^{2}$. For thaumatin the surface density was higher than proteinase $\mathrm{K}$ : after 20 depositions was around $16 \mathrm{mg} / \mathrm{mm}^{2}$. For lysozyme the surface density was the highest: after 20 depositions, it was around $32 \mathrm{mg} / \mathrm{mm}^{2}$. Despite different depositions of protein onto the quartz, the rate of deposition showed a direct proportional dependence on the number of immersion.

Results of nanogravimetric assay show that protein surface density increases with the number of layers (Figure 2). Therefore, this may represent an internal control and a validation of the correct deposition of protein into LB film (Figure 1).

\section{Comparison between crystal growth with and without LB template}

We tested the validity of LB template (made by 2 layers) growing crystals of our standard proteins.

For proteinase $\mathrm{K}$, after five days, average length of crystal grown with LB template was approximately three times larger than length

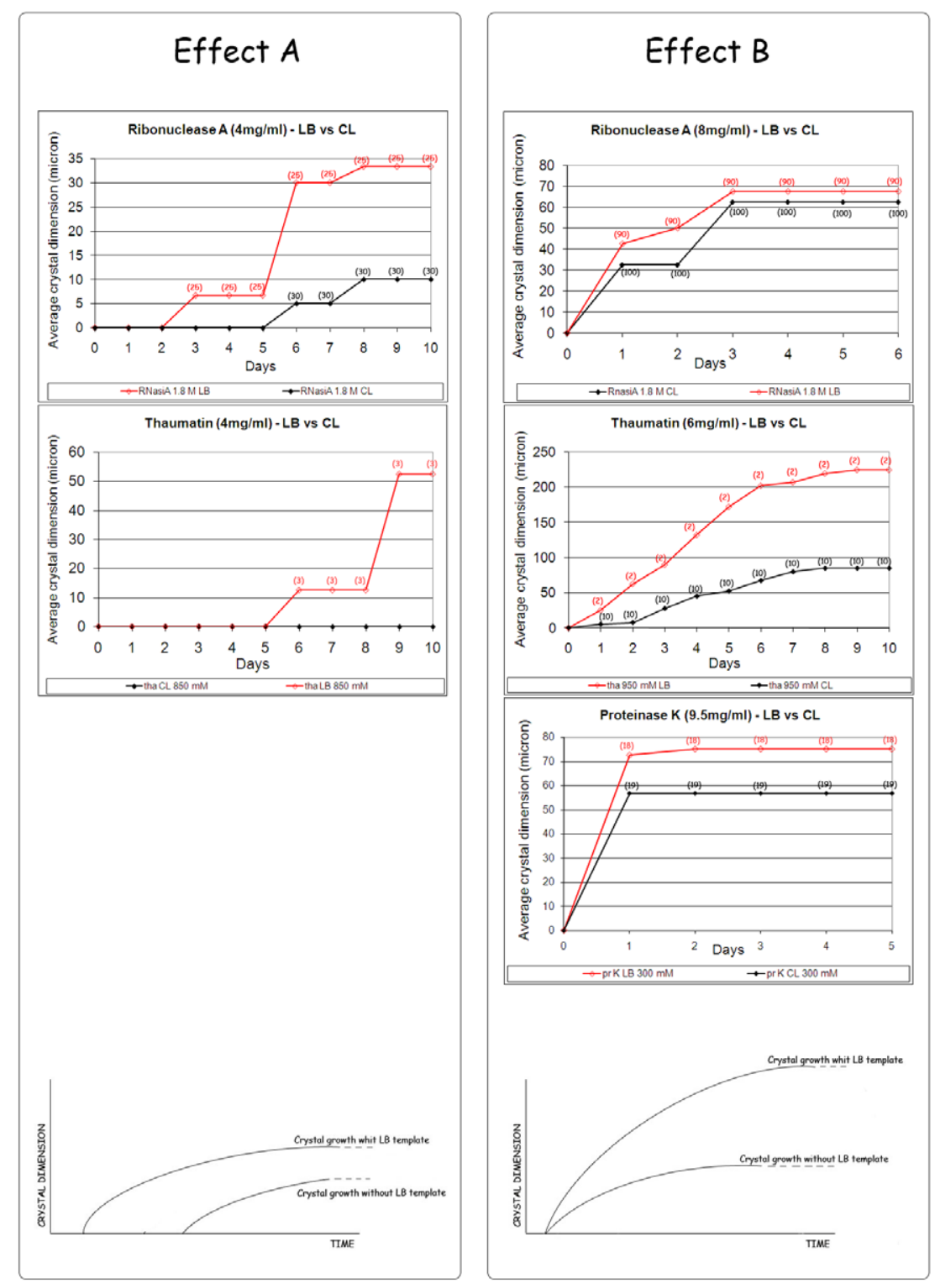

Figure 3: Effects of LB template in crystal growth (in brackets number of crystals), Effect A: template facilitates nucleation step. LB crystals grow earlier than classical, Effect B: template facilitates crystal growth. LB crystals grow larger than classical. 
of crystal grown without LB template: $450 \mu \mathrm{m} v s 138 \mu \mathrm{m}$ (Figure 3). For ribonuclease A, after three days, we found presence of crystals using LB thin film. With classical method, crystals grew only after six days. The difference in the average crystal dimension after ten days was approximately three times: LB crystals were $33 \mu \mathrm{m}$ while classical crystals were $10 \mu \mathrm{m}$ (Figure 4, Effect A - ribonuclease A).

For thaumatin, after six days, we found presence of crystals using LB thin film. With classical method, crystals did not grow (Figure 4, Effect A - thaumatin).

\section{Critical concentration}

After preliminary tests we have found the critical concentration after which there was not crystal growth. Starting from this concentration to zero, we grew protein crystal with and without LB template.

For proteinase $\mathrm{K}$ the critical concentration was $9.5 \mathrm{mg} / \mathrm{ml}$ with classical vapor diffusion method (Figure 5A). For thaumatin the critical concentration was $2 \mathrm{mg} / \mathrm{ml}$ with classical vapor diffusion method (Figure 5B). For crystals growth with LB template, after two weeks, protein concentration of $1.6 \mathrm{mg} / \mathrm{ml}$ was enough. For ribonuclease $\mathrm{A}$, the critical concentration was $4 \mathrm{mg} / \mathrm{ml}$ with classical vapor diffusion method (Figure 5C). For lysozyme, the critical concentration was $5 \mathrm{mg} /$ $\mathrm{ml}$ with classical vapor diffusion method.

We tried to verify if different number of protein film in the coverslide can affect crystal growth. We leaded experiments using: a control without LB template, and one with LB template (2, 5, 10 and 20 layers).

For ribonuclease $\mathrm{A}$ we tested different protein concentration, smaller than the critical concentration, and at $2 \mathrm{mg} / \mathrm{ml}$ of protein concentration best template in the cover-slides was made by 20 protein layers (Figure 3B).

In order to evaluate the role of LB thin film in crystal growth we tested decreasing salt concentration in the reservoir solution: we carried out a screening of crystal growth for a week, using same condition for all standard proteins.

We tried to find also a "salt critical concentration" for each protein, in order to combine the protein and salt concentration effects. We
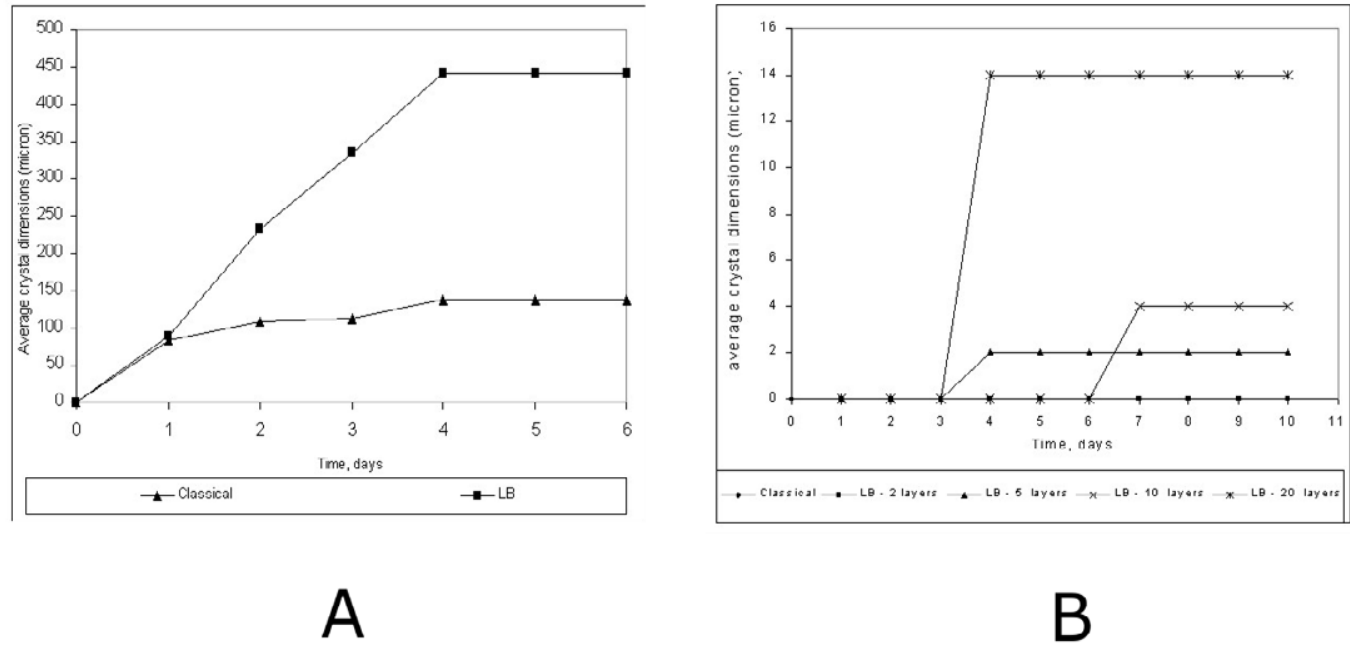

Figure 4: A) screening test for thaumatin "critical" concentration. B) screening test for ribonuclease A "critical" concentration. C: screening test for proteinase K "critical" concentration.

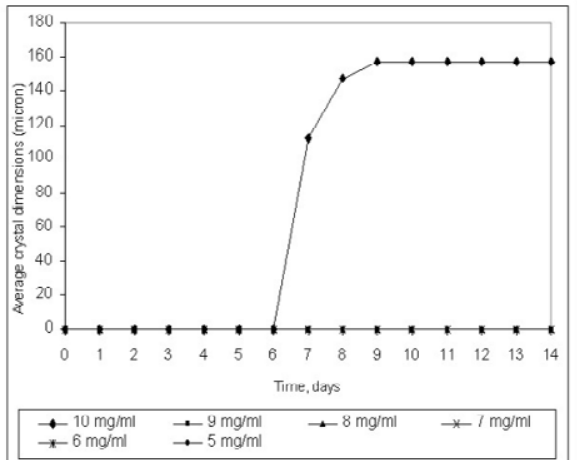

A

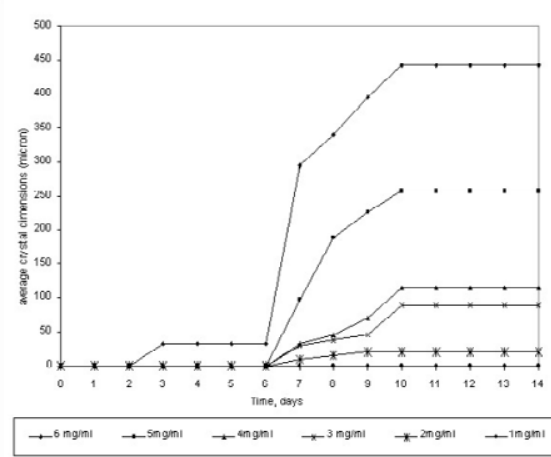

B
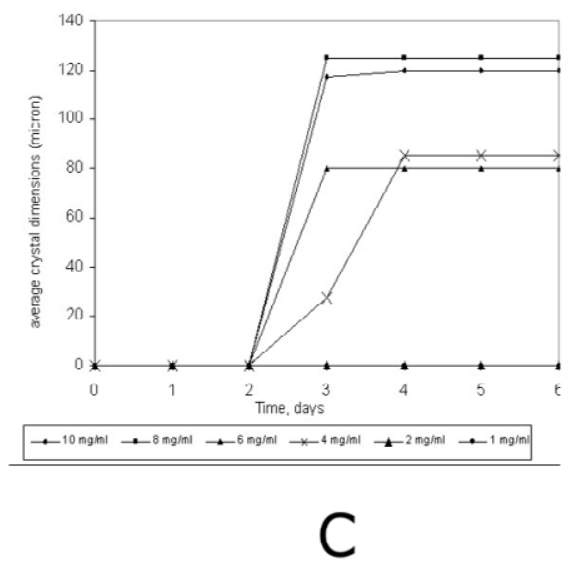

Figure 5: A) critical concentration for proteinase $\mathrm{K}$ with classical vapor diffusion method. B) critical concentration for thaumatin with classical vapor diffusion method. C) critical concentration for ribonuclease A with classical vapor diffusion method (Figure 5C). 
made different screening experiments for salt using different protein concentrations with and without LB template.

For lysozyme we tested different reservoir solutions, increasing sodium chloride concentration of $0.1 \mathrm{M}$ every time starting from $0.5 \mathrm{M}$ to $2.7 \mathrm{M}$. We used three protein concentrations: $10 \mathrm{mg} / \mathrm{ml}, 5 \mathrm{mg} / \mathrm{ml}$ and $3 \mathrm{mg} / \mathrm{ml}$. With classical method at $3 \mathrm{mg} / \mathrm{ml}$ of lysozyme, between $2.5 \mathrm{M}$ and 2.7 $\mathrm{M}$ of sodium chloride we could not observe crystal growth, but with LB template made by two layers, in the same conditions, crystals grew.

For proteinase $\mathrm{K}$, we changed sodium/potassium tartrate concentration of $0.05 \mathrm{M}$ starting from $0.2 \mathrm{M}$ to $0.35 \mathrm{M}$. We tested four different protein concentration $(13 \mathrm{mg} / \mathrm{ml}, 10 \mathrm{mg} / \mathrm{ml}, 9.5 \mathrm{mg} / \mathrm{ml}$ and $8 \mathrm{mg} / \mathrm{ml}$ ) using the classical and the LB method. We conducted LB experiments with 2, 10 and 20 layers. At $0.2 \mathrm{M}$ of sodium/potassium tartrate concentration crystals did not grow.

For thaumatin we changed sodium/potassium tartrate concentration of $0.05 \mathrm{M}$, starting from $0.8 \mathrm{M}$ to $0.95 \mathrm{M}$. We tested three different protein concentration $(8 \mathrm{mg} / \mathrm{ml}, 6 \mathrm{mg} / \mathrm{ml}$, and $4 \mathrm{mg} / \mathrm{ml})$ using the classical and the LB method. We conducted LB experiments with 2, 10 and 20 layers at $0.8 \mathrm{M}$ of sodium/potassium tartrate concentration crystals did not grow.

For ribonuclease A we changed sodium chloride concentration of $0.1 \mathrm{M}$, starting from $1.4 \mathrm{M}$ to $1.8 \mathrm{M}$. We tested three different protein concentration $(8 \mathrm{mg} / \mathrm{ml}, 6 \mathrm{mg} / \mathrm{ml}$, and $4 \mathrm{mg} / \mathrm{ml})$ using the classical and the LB method. We conducted LB experiments with 2, 10 and 20 layers.

We fond that, at protein critical concentration $(2 \mathrm{mg} / \mathrm{ml})$ using $1.8 \mathrm{M}$ of sodium chloride concentration, using same conditions for classical experiment, crystals grow only with 20 LB layers as template.

\section{Effects of LB template}

Crystals start growing by a process called nucleation. Nucleation can start with the molecules themselves or with the help of some solid matter already in the solution.

From several studies result that, in order to regulate nucleation, different materials can be used as template (silicate layer, porous silicon, self-assembled mono layers [12]).

For LB protein thin film template, also made by only 2 layers, we observed two different effects in crystal growth. The first effect, called "effect A", suggests that the template can facilitate the nucleation step. LB crystals grew earlier than classical crystals (Figure 4, Effect A). Second effect, called "effect B", suggest that the template can accelerate rate of crystal growth. LB crystals grew larger than classical crystals (Figure 4, Effect B).

Effect in crystal growth (effect B) can depend on the fact that, using LB with several layers of protein as template, proteins in the LB film dissolve in the drop and increase final protein concentration. This behavior was demonstrated using labeled protein for LB film formation: crystals grown with this template were also labeled [18].

Effect in nucleation (effect A) was already studied using inorganic compounds with irregular or rough surface or with cavities, but the effect was proven only in isolated cases [12].

Instead, with LB template the effect is a general effect. Using standard proteins (proteinase $\mathrm{K}$, thaumatin, ribonuclease $\mathrm{A}$ ) we found an increased nucleation.

The possible explanation of this behavior is that LB template operates whether like rough surface (demonstrated by AFM images [13]) or like nucleant agent by nonspecific attraction and local interactions between charged residues of protein in solution and ionizable group on LB template surface. Another possible explanation is that, from LB template, large aggregates of protein fall in drop. This aggregates can act as preformed center of nucleation. In this way the energy needed for nucleation and crystal growth is lower and crystals formation is facilitated.

Considering also number of crystals grown with and without LB template (Figure 4), we can affirm that generally number of crystals grown with LB template is lower than the number of crystals obtained with the classical method. This result suggests that protein thin film was involved in nucleation and in crystal growth, sometimes simultaneously like in effect $\mathrm{A}$.

These results confirm the models of crystal nucleation and growth proposed in previous $\mu$ GISAX studies [32-34] and extend the validity of LB protein thin film template behavior to all protein crystal growth.

Using robot and LB technologies various processing and structure parameters were compared in the Table 2 . Number of water molecules is less for LB based crystals compared to classical crystals. These water molecules were added at $1 \sigma$ for both classical and LB crystals. Less number of water molecules for LB based crystals are in agreement with our previously reported findings. Secondary structure obtained from two types of crystals is same. Electron density of different residues was compared at same contour level. Figure 6A shows the comparison of electron density map for classical and LB of carboxylic acid group of aspartic acid at 55 position. Figure $6 \mathrm{~B}$ shows the same comparison of disulphide bond of cystein at 71 position. Figure $6 \mathrm{C}$ shows the electron density comparison of disulphide bond formed by 149 cystein residue. Same density is plotted for proline residue at 135 position (Figure 6D). Figure $6 \mathrm{E}$ shows the comparison of electron density map of cysteine residue at 159 position of classical and LB crystal contoured at 2.5 sigma.

\section{Conclusions}

Protein nanocrystallography has recently been shown to produce diffracting, stable and radiation-resistant lysozyme crystals.

The nanotemplate-based hanging drop method, for instance, allowed a detailed study on the early steps of growth and nucleation of the lysozyme crystals, using microGISAX, at the ESRF, in Grenoble, France.

Results of the present study may be of high interest. In fact, we further prove the validity of the LB method, using well established model proteins such as ribonuclease $\mathrm{A}$, proteinase $\mathrm{K}$, thaumatin and lysozyme.

Validation via nanogravimetric analysis showed that the deposition of single different protein layers was homogeneous and uniformly spread onto the slide. We further verified that, even with these proteins, crystals obtained with LB-template are larger if compared to the ones grown with classical method. These results are in line with the ones obtained with lysozyme.

Noteworthy, using LB layers as a template, we are able to grow crystals at very low protein concentration, as in the case of ribonuclease $\mathrm{A}$.

Furthermore using LB thin film as template we obtained crystals in shorter time respect classical method and, for several protein and salt concentration, we obtained crystals only with LB method. 
Citation: Pechkova E, Fiordoro S, Barbieri F, Nicolini C (2014) The Role of Langmuir-Blodgett (Lb) Protein Thin Film in Protein Crystal Growth by Lb Nanotemplate and Robot. J Nanomed Nanotechnol 5: 247. doi: 10.4172/2157-7439.1000247

A

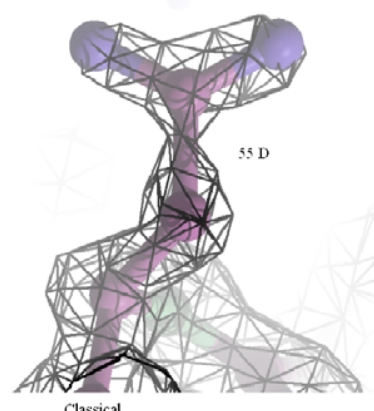

Classical

B

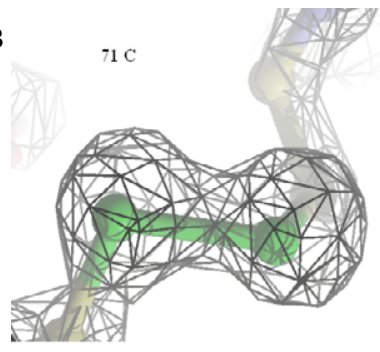

Classical
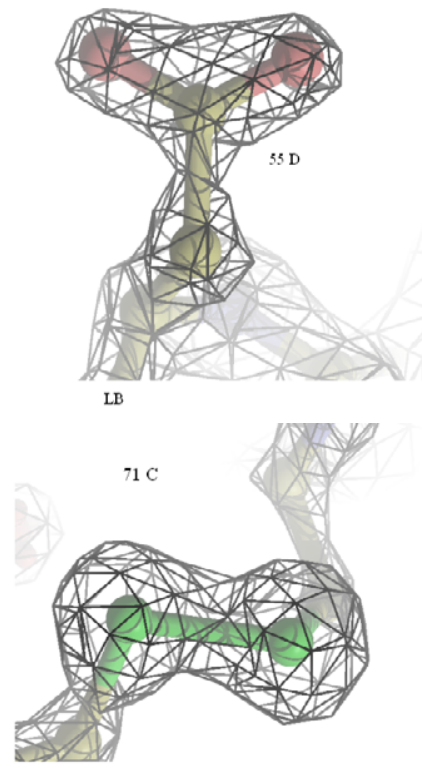

LB
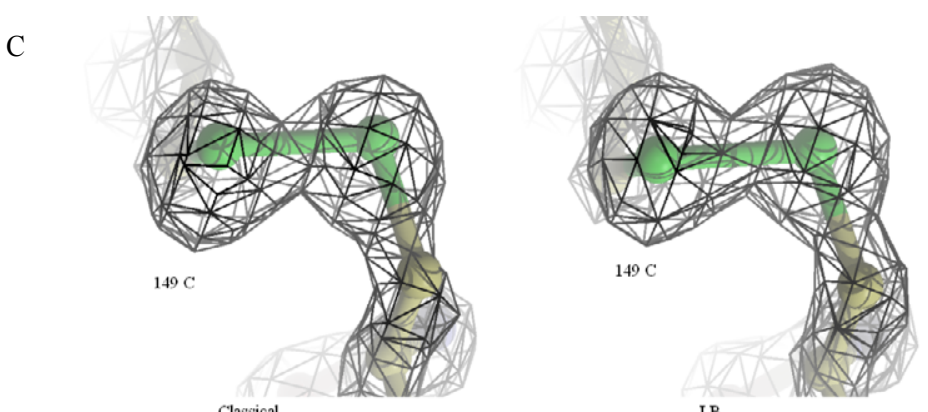

LB

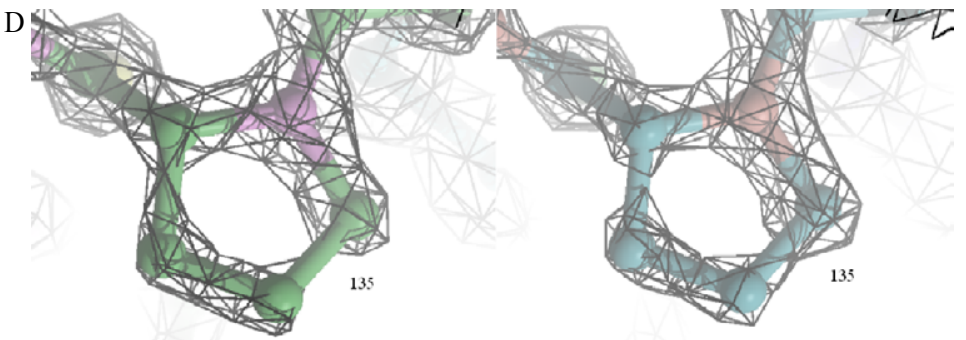

LB

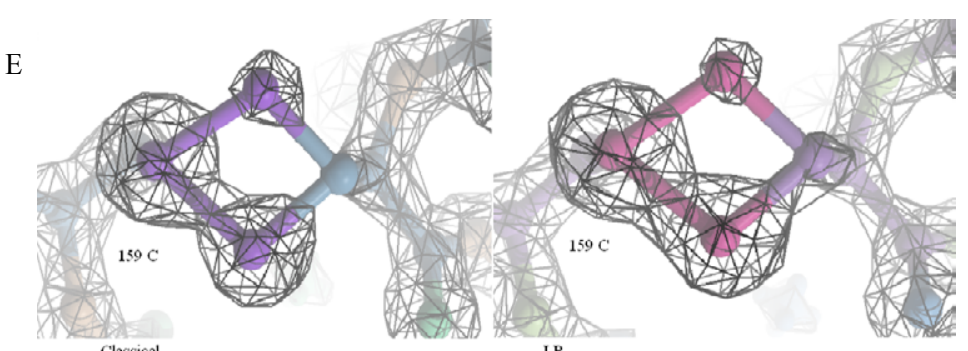

Figure 6: Electron density of crystals grown using robotic technique for LB-based nanotemplate method and classical method.. A) comparison of electron density map for carboxilic acid group of aspartic acid at 55 position contoured at 2.01 sigma. B) comparison of electron density map of disulphide bond of cystein residue at 71 position contoured at 2.5 sigma. C) comparison of electron density map of disulphide bond of cystein residue at 149 position contoured at 2.5 sigma. D) comparison of electron density map of proline residue at 135 position of classical and LB crystal contoured at 2.5 sigma. E) comparison of electron density map of cysteine residue at 159 position of classical and LB crystal contoured at 2.5 sigma. From left to right and frpm top down. 
Citation: Pechkova E, Fiordoro S, Barbieri F, Nicolini C (2014) The Role of Langmuir-Blodgett (Lb) Protein Thin Film in Protein Crystal Growth by Lb Nanotemplate and Robot. J Nanomed Nanotechnol 5: 247. doi: 10.4172/2157-7439.1000247

Taken together, these findings further confirm that nanocrystallography is moving from its "art" to its "science" state. In fact, results of the present and of previous studies show that the protein micro-crystals obtained by nanotechnology-based protein thin-film template crystallization, as well as groundbreaking technology, such as atomic force microscopy (AFM, 35), nanogravimetry and synchrotron microfocus, have enabled protein nanocrystallography to be defined as a unique technology capable of forming and characterizing stable protein microcrystals down to atomic resolution scale.

This new methodology will likely allow to shed new lights on several systems that are still unsolved with standard crystallography techniques.

\section{Acknowledgment}

This research was supported by a FIRB grant on "Functional Proteomics and Cell Cycle Progression" (RBIN04RXHS) from MIUR (Ministry of University and Research of Italy) to Professor Claudio Nicolini then Director of CIRSDNNOB, University of Genoa, and by a MIUR (Ministry of University and Research of Italy) grant for Funzionamento to Fondazione ELBA Nicolini.

We acknowledge precious cohoperation of Dr. Josè Antonio Marquez, Dr. Manju Singh and Dr. Dora Scudieri, as well as of the staff of the ESRF.

\section{References}

1. Pechkova E, Riekel C (2011) Synchroton Radiation and Structural Proteomics Pan Stanford Series on Nanobiotechnology 3: 1-430

2. Pechkova E, Nicolini C (2004) Protein nanocrystallography: a new approach to structural proteomics. Trends Biotechnol 22: 117-122.

3. Pechkova E, Zanotti G, Nicolini C (2003) Three-dimensional atomic structure of a catalytic subunit mutant of human protein kinase CK2. Acta Crystallogr D Biol Crystallogr 59: 2133-2139.

4. Giegé R, McPherson A (2001) Part 4: Crystallization. 81-110, in: Rossmann MG, Arnold E (Editors) International Tables for Crystallography. Volume F: Crystallography of Biological Macromolecules.

5. Nagy ZK, Chew JW, Fujiwara M, Braatz RD (2008) Comparative performance of concentration and temperature controlled crystallizations. J Process Control 18: 399-407.

6. Nyce TA, Rosenberger F (1991) Growth of protein crystals suspended in a closed loop thermosyphon. J Cryst Growth 110: 52-59.

7. Lorber B, Ng JD, Lautenschlager P, Giegé R (2000) Growth kinetics and motion of thaumatin crystals during USML-2 and LMS microgravity missions and comparison with earth controls. J Crystal Growth 208: 665-677.

8. Pechkova E, Tripathi S, Ravelli RB, McSweeney S, Nicolini C (2009) Radiation stability of proteinase $\mathrm{K}$ crystals grown by LB nanotemplate method. J Struct Biol 168: 409-418.

9. Pechkova E, Scudieri D, Belmonte L, Nicolini C (2012) Oxygen-bound Hell's gate globin I by classical versus LB nanotemplate method. J Cell Biochem 113 2543-2548.

10. Blow DM, Chayen NE, Lloyd LF, Saridakis E (1994) Control of nucleation of protein crystals. Protein Sci 3: 1638-1643.

11. McPherson A, Shlichta P (1988) Heterogeneous and epitaxial nucleation of protein crystals on mineral surfaces. Science 239: 385-387.

12. Takehara M, Ino K, Takakusagi Y, Oshikane H, Nureki O, et al. (2008) Use of layer silicate for protein crystallization: effects of Micromica and chlorite powders in hanging drops. Anal Biochem 373: 322-329.

13. Pham T, Lai D, Ji D, Tuntiwechapikul W, Friedman JM, et al. (2004) Wellordered self-assembled monolayer surfaces can be used to enhance the growth of protein crystals. Colloids Surf B Biointerfaces 34: 191-196.

14. Abola E, Kuhn P, Earnest T, Stevens RC (2000) Automation of X-ray crystallography. Nat Struct Biol 7 Suppl: 973-977.

15. Whittingham JL, Scott DJ, Chance K, Wilson A, Finch J, et al. (2002) Insulin at $\mathrm{pH}$ 2: structural analysis of the conditions promoting insulin fibre formation. $J$ Mol Biol 318: 479-490.
16. Okutsu T (2007) Photochemically-induced crystallization of protein. J Photochem Photobiol C 8: 143-155

17. Pechkova E, Sivozhelezov V, Belmonte L, McSweeney S, Nicolini C (2012) Unique water distribution of langmuir-blodget versus classical crystals. Journa of Structural Biology 180: 57-64.

18. Pechkova E, Fiordoro S, Fontani D, Nicolini C (2005) Investigating crystalgrowth mechanisms with and without LB template: protein transfer from LB to crystal. Acta Crystallogr D Biol Crystallogr 61: 809-812.

19. McPherson A (1999) Crystallization of Biological Macromolecules. Cold Spring Harbor Laboratory Press, Cold Spring Harbor, New York, USA.

20. Chayen NE, Boggon TJ, Cassetta A, Deacon A, Gleichmann T, et al. (1996 Trends and challenges in experimental macromolecular crystallography. $Q$ Rev Biophys 29: 227-278.

21. Maxia L, Radicchi G, Pepe IM, Nicolini C (1995) Characterization of LangmuirBlodgett films of rhodopsin: thermal stability studies. Biophys J 69: 1440-1446

22. Facci P, Erokhin V, Nicolini C (1994) Scanning tunnelling microscopy of a monolayer of reaction centres. Thin Solid Films 243: 403-406.

23. Nicolini C (1997) Protein-monolayer engineering: principles and application to biocatalysis. Trends Biotechnol 15: 395-401.

24. Pechkova E, Nicolini C (2002) From art to science in protein crystallization by means of thin film technology. Nanotechnology 13: 460-464.

25. Pechkova E, Nicolini C (2002) Protein nucleation and crystallization by homologous protein thin film template. J Cell Biochem 85: 243-251.

26. Facci P, Erokhin V, Nicolini C (1993) Nanogravimetric gauge for surface density measurements and deposition analysis of Langmuir-Blodgett films. Thin Solid Films 230: 86-89.

27. Pechkova E, Nicolini C (2001) Accelerated protein crystal growth onto the protein thin film. J Crystal Growth 231: 599-602.

28. Pechkova E, Tropiano G, Riekel C, Nicolini C (2004) Radiation stability of protein crystals grown by nanostructured templates: synchrotron microfocus analysis. Spectrochimica Acta B 59: 1687-1693.

29. Murshudov GN, Skubák P, Lebedev AA, Pannu NS, Steiner RA, et al. (2011) REFMAC5 for the refinement of macromolecular crystal structures. Acta Crystallogr D Biol Crystallogr 67: 355-367

30. Cipriani F, Röwer M, Landret C, Zander U, Felisaz F, et al. (2012) CrystalDirect: a new method for automated crystal harvesting based on laser-induced photoablation of thin films. Acta Crystallogr D Biol Crystallogr 68: 1393-1399.

31. Márquez JA, Cipriani F (2014) CrystalDirectâ, $\phi$ : a novel approach for automated crystal harvesting based on photoablation of thin films. Methods Mol Biol 1091 197-203.

32. Nicolini C, Pechkova E (2006) Structure and growth of ultrasmall protein microcrystals by synchrotron radiation: I. microGISAXS and microdiffraction of P450scc. J Cell Biochem 97: 544-552.

33. Pechkova E, Nicolini C (2006) Structure and growth of ultrasmall protein microcrystals by synchrotron radiation: II. microGISAX and microscopy of lysozyme. J Cell Biochem 97: 553-560.

34. Gebhardt R, Pechkova E, Riekel C, Nicolini C (2010) In situ muGISAXS: I. Experimental setup for submicron study of protein nucleation and growth Biophys J 99: 1256-1261. 